\section{Prostate Health Index}

S. Holdenrieder

Institut für Laboratoriumsmedizin, Deutsches Herzzentrum München, Klinik an der Technischen Universität München, München, Deutschland

Synonym(e) PHI; phi

Definition PHI ist eine Rechengröße, die Gesamt-PSA (tPSA), freies PSA (fPSA) und [-2]proPSA kombiniert und errechnet sich wie folgt: PHI $=([-2]$ proPSA/fPSA $) \times$ $(\text { tPSA) })^{1 / 2}$. Die Kombination der Marker innerhalb von PHI zeigte sich bei der Diagnostik des Prostatakarzinoms im PSA-Bereich 2-10 ng/mL den Einzelparametern überlegen. In einer multivariaten Studie wurde die Überlegenheit von PHI gegenüber Gesamt-PSA und \%fPSA zur Detektion eines
Prostatakarzinoms im PSA-Bereich 2-10 $\mathrm{ng} / \mathrm{ml}$ bei der initialen und wiederholten Biopsie bestätigt. Somit eignet sich PHI zur Patientenberatung vor einer Biopsie.

\section{Literatur}

Boegemann $\mathrm{M}$ et al (2016) The percentage of prostate-specific antigen (PSA) isoform [-2]proPSA and the Prostate Health Index improve the diagnostic accuracy for clinically relevant prostate cancer at initial and repeat biopsy compared with total PSA and percentage free PSA in men aged $\leq 65$ years. BJU Int 117:72-79

Jansen FH et al (2010) Prostate-specific antigen (PSA) isoform p2PSA in combination with total PSA and free PSA improves diagnostic accuracy in prostate cancer detection. Eur Urol 57:921-927

Sokoll LJ et al (2010) A prospective, multicenter, National Cancer Institute Early Detection Research Network study of [-2]proPSA: improving prostate cancer detection and correlating with cancer aggressiveness. Cancer Epidemiol Biomarkers Prev 19:1193-1200 